DOI: $10.17516 / 1997-1370-0570$

УДК 902/904

\title{
Lunar Images in the Cultural Traditions in the South of Western Siberia in the Second Half of the 3rd - the Beginning of the 2nd Millennium BC
}

\author{
Igor V. Kovtun \\ The Federal Research Center of Coal and Coal Chemistry of SB RAS \\ Kemerovo, Russian Federation
}

Received 10.10.2019, received in revised form 27.02.2020, accepted 28.04.2020

\begin{abstract}
The article highlights a series of multicultural images of the developed Bronze Age of the south of Western Siberia, which are connected by a common semantic meaning. The author substantiates lunar semantics of Okunev, Krokhalevka and Samus anthropomorphic characters conveying the idea of significant moon cycles, mainly the new moon, the first quarter and the full moon. The worldviews of the population of these cultures are reconstructed, the probable sources of the lunar cult and the peculiarities of similar views in each community are investigated. Specific iconographic methods of transmitting similar ideological stereotypes by various visual means inherent in the cultural groups of the Upper Ob Region, the Lower Tom Region and the Middle Yenisei in the second half of the $3^{\text {rd }}$ - the beginning of the $2^{\text {nd }}$ millennium $\mathrm{BC}$ are revealed.
\end{abstract}

Keywords: lunar images, south of Western Siberia, Okunev culture, Krokhalevka culture, Samus culture, worldview, fine art, ornamental graphics.

Research area: archeology.

Citation: Kovtun, I.V. (2020). Lunar images in the cultural traditions in the south of Western Siberia in the second half of the $3 \mathrm{rd}$ - the beginning of the 2 nd millennium BC. J. Sib. Fed. Univ. Humanit. Soc. Sci., 14(1), 49-68. DOI: 10.17516/1997-1370-0570.

(C) Siberian Federal University. All rights reserved

* Corresponding author E-mail address: ivkovtun@mail.ru 


\section{Introduction}

In 2017, a subsoil burial ground of the developed Bronze Age was discovered and examined in the central part of Novosibirsk on the right bank of the Ob River, near the mouth of the Inya River at the settlement of Turist-2. Ceramics of the Krokhalevka and Krotovo images were found in a number of burials of this unique monument. Works of fine art were also found here (Basova et al., 2017: 509-512; Basova, 2018: 209-213; Zaika et al., 2018). Their significance for the philosophical and cultural-historical interpretation of a number of West Siberian graphic complexes of the Bronze Age - Early Iron Age is hard to overestimate.

Currently, only two pieces of fine art from those discovered in the burial places of Tourist-2 have been published. But even these findings make it possible to draw a number of significant parallels with the images of the synstadial cultures of the Altai Mountains, the Lower Tom Region and the Middle Yenisei.

\section{A pike and the full moon}

A plate, as the authors call it, made of polymer materials was found in the burial 1 in Tourist-2; it was located above the left pelvic bone of a buried body. This item depicts a multi-figure composition comprising three full-length anthropomorphic characters and two pike heads (Zaika et al., 2018) (Fig. 1). The upper part of the left figure is lost, but by means of a computer "cast" from the preserved symmetrical image, it was possible to reconstruct the appearance of the whole composition as a whole (Fig. 2).

The central image is full-face and crowned with a headwear consisting of fifteen symbolic rays. Side characters are captured in profile, and the visible part of their headgear consists of six rays from each flanking figure (Fig. 2; $3,1)$. Symbolization of these numerical values implied meaningful plans related to the full moon and other significant phases of the moon. The number "fifteen" corresponds to the middle of a lunar month, according to the number
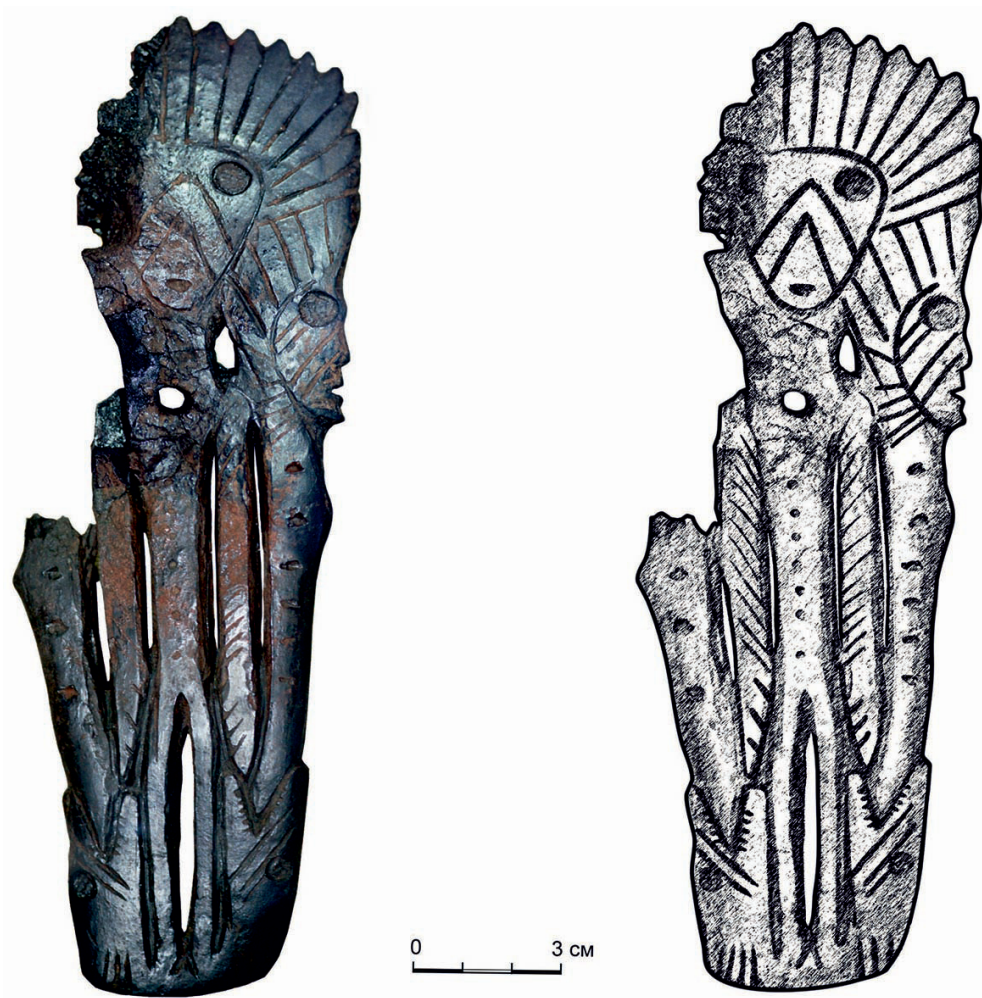

Fig. 1. Polyfigured composition. Burial No. 1, Turist-2 (photo by I.V. Kovtun) 

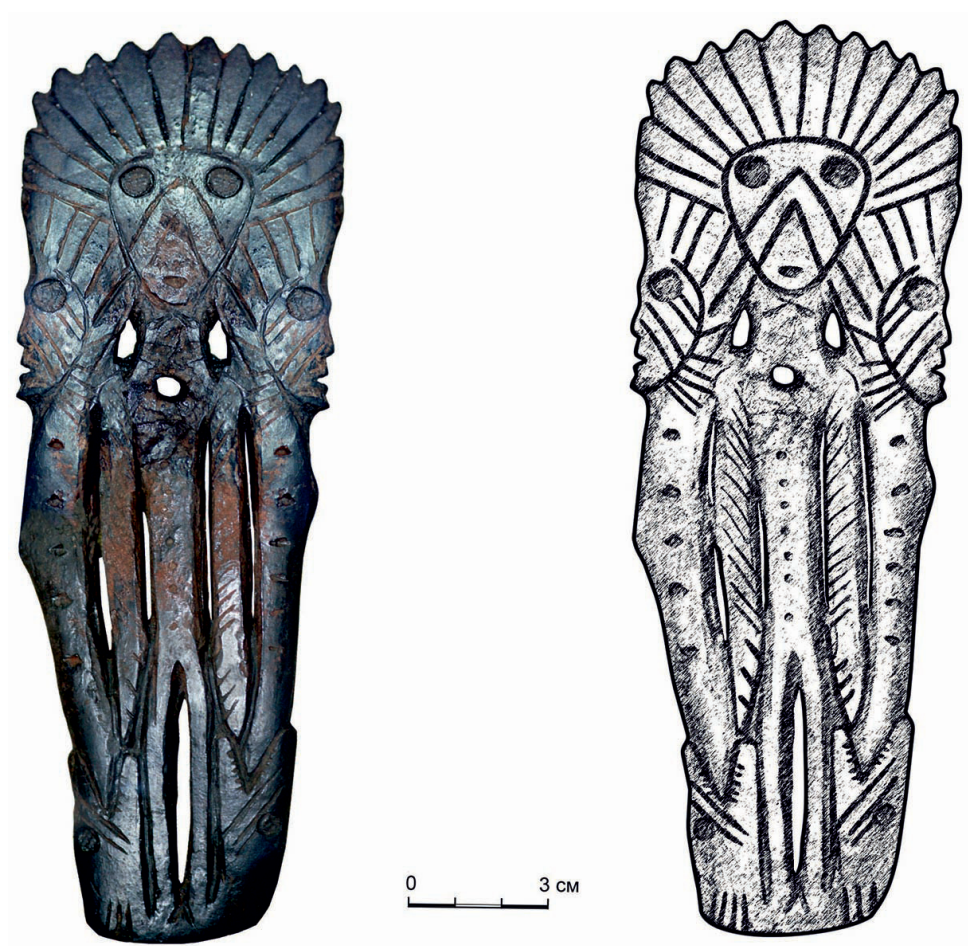

Fig. 2. Polyfigured composition. Burial No. 1, Turist-2. Reconstruction

of days elapsed from the new moon to the full moon. This number of days marks the end of the first half of a lunar, synodic month, which is about 29.5 days. Since the moon is not visible during the new moon for about 1.5 days, the duration of its visibility is 28 days or four weeks corresponding to the first quarter, the full moon, the last quarter and the new moon (Seleshnikov, 1970: 166; Klimishin, 1985: 34, 40). Moreover, in various worldview traditions of the Indo-European and Siberian peoples, the full moon phase was associated with the fourteenth, fifteenth and, much less frequently, with the sixteenth days of the month.

Many peoples attached a very special meaning to the full moon (Eliade, 1999: 162163; Kovtun, 2014: 92-94). The deification of the full moon phase dates back to archaic mythological calendar representations comparable only to the scale of the sun worship. For example, the Kets believed that: "the new-born month began its journey low above the ground, and every evening rose higher. In the first seven days, it reached the second circle (headland) of heaven, and on the fourteenth day it found itself at the place of its stay - the fourth circle... On the second circle it was already in the form of a semicircle, and the fourth circle became round" (Alekseenko, 1976: 83). According to the Mansi: "In the underworld, the moon is only half, the full moon does not exist there" (Istochniki, 1987: 152). The connection of the growing moon with fertility is observed in the ideas of both Indo-European and non-Indo-European peoples (Eliade, 1999: 162-163). Therefore, the apogee of the vital principle opposed to the world of the dead was associated with the full moon. Hence the idea of a victim confined to a specified calendar period of the lunar cycle and designed to ensure abundance and well-being. The Mansi sacrificial blankets - yalpyn, with the image of Mir-Susne-Khum (less often than his mother Kaltash-Ekva or Kaltas-imi among the Khanty, as well as the "bride"), at the same time personifying a "saddle of God" and his "horse", began to be made "at the half moon", and finished "at the full moon" (Gemuev, 1990: 35-37). Such correlation of the 


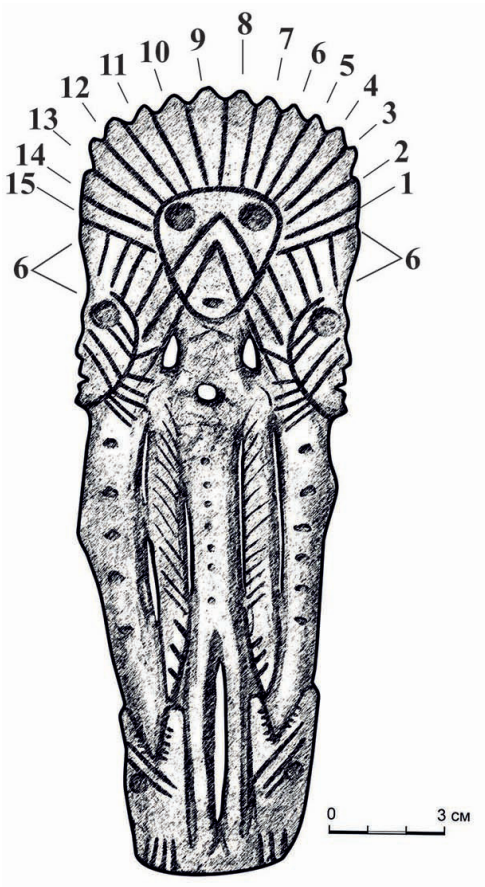

1

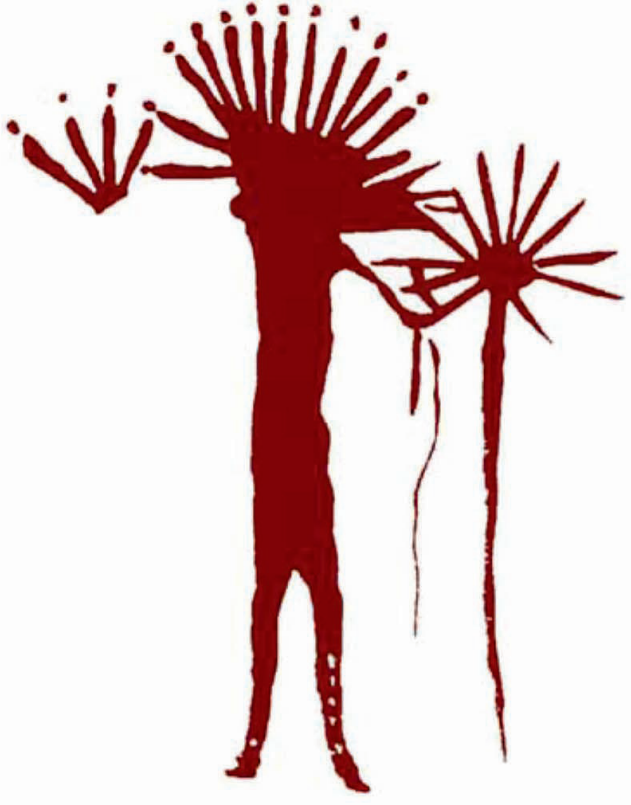

2

Fig. 3. Numerical symbolizations. 1 - Polyfigured composition. Burial No. 1, Turist-2. Reconstruction; 2 - Karakol, plate 6, grave 5

time of the production of sacrificial attributes with the full moon phase is not accidental. In the cultural traditions of the Mansi, borrowed Indo-Aryan elements were revealed (Kovtun, 2013: 59, et al), and the Vedic Aryans called a night of the full moon "the first worthy night of sacrifice" (Atkharvaveda (Shaunaka), VII. 85. 1, 2, 4). The image of the "full moon" also appears in a Altaian horse sacrifice ceremony (Eliade, 2000: 188).

A figurative image of the full moon in the composition from Turist-2 also correlates with the representations of chronologically synchronous Seima-Turbino groups. The idea of the New Year full moon and the horse sacrifice being performed at that time is personified by an openwork lattice of a Seima knife, a righthand side view of an Omsk knife crowned with a horse pair, the ornamentation of a Rostovka celt-spade with the image of a goat, and probably a twelve-piece pseudo-winding of a Shemonaikha dagger (Kovtun, 2013: 147, 218-219, 319-320, 343-344), an ornamental composition of an Omsk dagger blade with a ring crest, protrusions on the handles of daggers from the Second Karakol treasure, from the Tianshui county of Gansu province, from Charyshskoe village, and from the burial 425 in Sopka-2/4B (Kovtun, 2017: 111-113).

In addition to the central figure personifying the full moon in the composition from Turist-2, there are two profile side characters. A characteristic feature of these images are the mirror symmetry and the profile transmission of images. In this composition, the profile projection is exactly half of the whole symbolized by the central character. Therefore, if the central full-face image represents the full moon, then the side profile images symbolize "half the moon", i.e. crescent. Such halfness transmitted by the profile projection corresponds to the characteristic features of two lunar phases: the first and the last quarters. In the Northern hemisphere, the visible part of the growing and the decrescent moon visually grows and decreases from right to left. Therefore, the first 
lunar quarter was implied by the right, preserved figure, and the last, probably lost, but hypothetically reconstructed lunar quarter - by the left one (Fig. 2).

A characteristic feature of the head of these images is represented by profile head accessories with six "rays" (Fig. 3, 1). With an imaginable projection into the full face, the number of "rays" will proportionally double and will amount to twelve. This is exactly how one of the Karakol compositions was performed, structurally resembling the one under study, where the side character has exactly twelve "rays" (Fig. 3, 2). But the creators of the composition from Turist-2 did not deploy side figures full-face. Therefore, a different number of symbolic "rays" may indicate a different semantic meaning. It is possible that this is the quantitative symbolization of the lunar phases and the time before the full moon signified by the central character. Consequently, the right figure symbolized the first quarter, which came six days before the full moon, and the left one the last quarter, which came six days after it. The full moon retains this shape from about the fifteenth to the eighteenth lunar day, including the period of the invisible moon. Hence the possible discrepancies in the calculation of the day with a well-visible limb and without it. Accordingly, the countdown of the lunar day from the moment of waxing crescent excludes at least two days of the invisible moon. Even on the third day, the visibility of the limb is very slight. Therefore, the periods of visible lunar phases differ from astronomical ones. Obviously, visual observations were a guideline for the non-literate cultures of North-West Asia of the Bronze Age, and the time of the invisible moon could be taken into account only in calendar calculations.

A diagnostic sign of flanking images is the lines extending from their left and, accordingly, right "cheeks" called "whiskers" (Fig. 2). Similar accessories appear on a number of the Okunev images made on steles, ceramics, as well as on a number of cave paintings (Fig. 4). In a stylized but recognizable form, typologically similar elements accompany a series of Samus anthropomorphs (Fig. 7-9). According to the argumentation below, "whiskers" are an exceptional attribute of the Okunev and Samus lunar characters. This confirms the reconstructed substantial plan of the two side figures of the composition from Turist-2, which meant a growing and decreasing crescent, before and after the full moon.

The place of finding of the two plates with images above the left pelvic bone certifies their presence on a belt of the buried body from the grave lin Turist-2. It is well known that the shaman's belt, along with a tambourine, a clapper and a headdress, was one of the most important accessories. Shaman's belt could have images of spirit helpers, other attributes and tools of ritual practices. Therefore, findings from the grave 1 in Turist- 2 suggest that the person buried there participated in ritual ceremonies during the worship of the lunar cult as a "proto-shaman" of the Krokhalevka period. Finally, it is unlikely that a cosmographic composition reflecting the fundamental principles of the world order and calendar cycles would end up in the burial place of an ordinary buried person.

The image of the full moon in the composition from Turist-2 seems to be the central plot motif of a multifaceted cosmographic plan. In this pictorial narrative, the ideas of the alleged Krokhalevka residents about the structure and driving principles of the universe are revealed. The composition and location of the acting characters resemble the compositional and symbolic formula of the etiological myth underlying the worldview doctrine of Krokhalevka's society.

Symmetric images of the heads of two pikes (or "snake-pikes") grabbing or spewing flanking characters are noteworthy (Fig. 2). The connection of a pike with the Lower World is confirmed not only by numerous ethnographic evidences, but also by the very composition in which pikes are assigned to the lowermost tier. A pike seemed to be the owner of ponds, or the owner of water and ponds appeared in the form of a pike. Frequently other, more often negative, mythological figures also turned to pikes (Grysyk, 1992: 57-59). For example, in the Nenets epos, the spirit of water Id Erv, the iron pike Yesyadavy Pyri, was in the guise of the Horned Pike (Khariuchi, 2008: 284), and a chest with a figure of the Pike God was in 

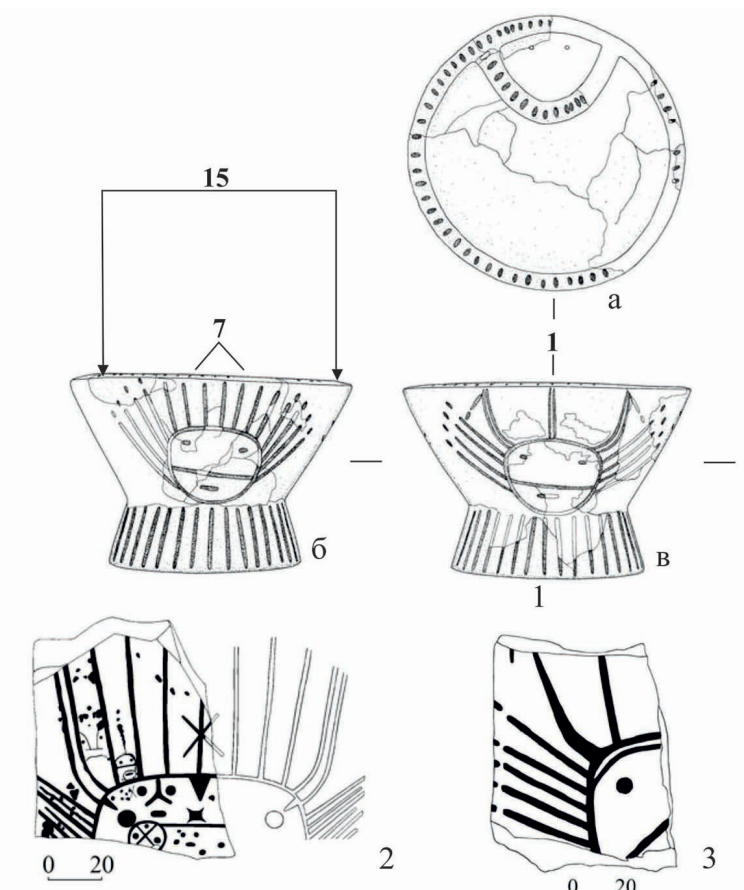

2
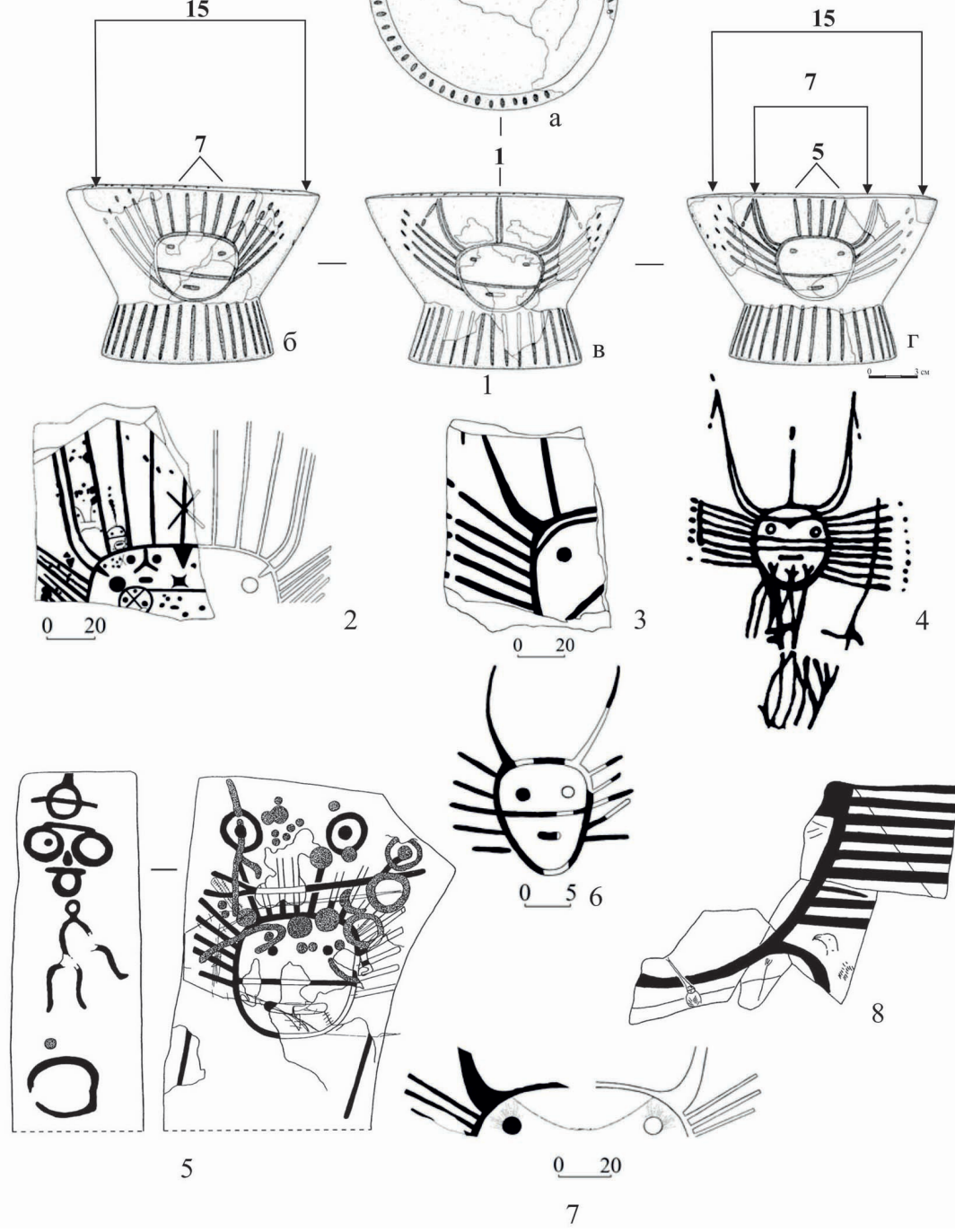

Fig. 4. Okunev images and fragments with images of lunar characters. 1 - Itkol II, burial mound 12, grave 3; 2 - Shirinsky District of Khakassia; 3 - Itkol II, burial mound 12, grave 10; 4 - Shalabolinskaya pisanitsa; 5 - a stele from a burial mound on the Tabat River; 6 - Big ring, grave 3-K; 7 - Tas-Khazaa; 8 - a fragment of a stele from Tas-Khazaa burial mound

the sacred tree stand of the forest Nenets on the Pusym-to River (Spodina, 2001: 83).

Chthonic and reptilian fantastic characters were often portrayed as striving to absorb the sun and the moon. This archaic and transcultural mythological motif is prevalent throughout the world. For example, in ancient Indian mythology, such a character is the dragon-like demon Rahu. He drank the Amrita and his immortal head ascended into heaven, periodically swallowing the moon and the sun (Grintser, 1994: 372; Temkin, Erman, 2000: 115). The composition from Turist-2 also featured only pike heads. 
It is interesting that in the Ob-Ugric ethnic names associated with representations of the totem ancestor, two "pike" ethnonyms were identified: "a pike" - Soinakh - "pike (people of the ancestor of a pike)", Sortyn-yakh - "pike people" (Kruchinina, 2004: 14). The forest Nenets also had the Pike tribe (Spodina, 2001: 8). At the same time, in the cosmogony of many peoples, including the Volga-Ural and Siberian ethnic groups, fish seemed to be the significant foundation on which the universe rests. According to the updated classification of Iu.E. Berezkin and E.N. Duvakin, such ideas were widespread among the Udmurts, Mordovians, Chuvashs, Tatars, Bashkirs, Shors, Siberian Tatars, Nenets, Khanty, Mansi, Northern Selkups, Buryats, Evenks, etc. According to the views of northern Selkups, mammoths and a fish support the land, and the mammoth itself was represented in the form of a huge pike with a head covered with green moss. The Evenki believed that beyond the extreme land of the Lower World there is water, in which two perches and two pikes swim, and the universe - buga - rests on their backs, etc. (Berezkin, Duvakin, 2018).

Obviously, the composition from Turist-2 organically combines both of the archaic calendar-cosmogonic motifs. The Pike of the Lower World supporting the Universe is compositionally involved in two lunar phases and in side characters meaning these phases. Symmetrical pike heads come in contact with profile figures with an open mouth and, therefore, are directly connected with them by the plot. But the content of these seemingly similar subcompositions is different. The figure of the left (from the observer), profile embodiment of the last lunar quarter is swallowed by the pike, which corresponds to the rapid disappearance of the visible moon. The image of the right character, meaning the first quarter and the growing moon, is belched by the pike. This semantic plan symbolizes the beginning of the lunar month and demonstrates the return of the visibility of the limb two days after the new moon (Fig. 2).

Thus, the entire composition from Turist-2 conveys the calendar cycle of the lunar month and is "read" from right to left. Such direction and sequence repeat the real direction of the visible increase in the growing, and then decrease in the waning moon. The right profile figure and pike meant the beginning of the month and the growth of the moon to the crescent phase - the first lunar quarter. This is followed by the main character of the composition, with a full-face contour and a "fifteen-rayed" halo. This figure occupied a central position and personified the full moon. Finally, the left, reconstructed image of the waning moon devoured by the Pike of the Lower World, symbolized the crescent in the third quarter phase, its subsequent descent and disappearance to a new cycle.

\section{Lunar phases and lunar hypostases}

An adequate substantive parallel to the "trinity" from Turist-2 was found in grave 3, mound 12 of the Okunev burial ground Itkol II. It is a censer with images of three masks, in various variations of head accessories (Fig. 4, 1). The masks are completely similar in the reproduction of a facial contour, as well as in its filling with the signs of two eyes, a mouth and a horizontal strip separating them. The lateral attributes of all the masks are equally decorated, in the form of eight diagonally raised eight lines with dots, four on each side. It is typologically significant that these "whiskers" do not extend from the upper part of the masks, but from two sides, from the right and left "cheeks" (Fig. 4, 1).

The authors of the publication interpret the mask with bull horns and the least number of "rays" as "the central image of a three-part composition with asymmetric side images", assigning a connecting role to this image (Poliakov and Esin, 2017: 343, Fig. 4). The mask with two bull horns and one "ray" between them is really located on the diametrically opposite side of the compartment with two holes for tying (Fig. 4, 1 a, B). But it makes this image not the centre, but the beginning of a pictorial narrative. The storyline develops in a circle, as the number of "rays" in the upper part of the two subsequent masks increases.

Thus, at the conditionally starting point of the composition, the first mask has two bull horns and one "ray" (Fig. 4, 1 B). A turn of the censer from right to left opens up a new per- 
spective of the depicted character that also has two horns, but with five "rays" (Fig. 4, 1 г). A further turn of the censer in this direction leads to the emergence of the next image on the right, which is qualitatively different from the two previous ones. The third mask lost its bull horns, but is endowed with seven rays that are compositionally merged with the "whiskers" into a single halo (Fig. 4, 1 б). The total number of "rays" and "whiskers" on the third mask is "fifteen" that is the quantitative symbolization of the image of the full moon. It is confirmed by the absence of bovine horns on this mask that are symbolizing the crescent, which disappears with the full moon (Fig. 4, 1 б).

The associative connection of bull horns and a crescent is present in the mythological traditions of Western Asia. For example, in Sumerian religion, the starry night deity is known as the moon god Sin, or Nanna/Nannar floating in his barge at night in the sky. A bull was associated with this deity. Its horns form a crescent and this crescent was a sign of the god Sin/Nannar (Afanas'eva, 1994: 198). In other cases, the crescent of Sin was compared to the horns of a "playful heavenly calf" (Iakobsen, 1995: 146).

That is why bull horns appear on the images of the two previous masks, personifying lunar phases with visible "horns" of the crescent. The summation of the five rays of the second mask with its two horns gives "seven", which corresponds to the phase of the first lunar quarter - a median between the new moon and the full moon, when the moon is half visible (Fig. 4, 1 г). Finally, the initial mask with two horns and one "ray" corresponds to the symbolic signs of the new moon phase (Fig. 4, 1 в). But since the moon is not visible during the new moon, this mask symbolizes the first day of the visible crescent. Hence, one "ray" between the horns of the initial mask, which represents the image of the first day of the new calendar cycle, and the beginning of the lunar month.

The principle of a symbolic portrayal of the new moon does not coincide with the method of quantitative symbolization of the first quarter, and both of them differ from the presentation of the key numerical sign of the full moon. The new moon represents bull horns, as an allegory of the young crescent and one ray meaning the first visible day of the growing moon (Fig. 4, 1 в). The numerical value of the first quarter is the summation of five rays and two bull horns, which symbolized the image of the crescent (Fig. 4, 1 г). At the full moon, the "horniness" of the crescent disappears, giving way to the full moon. Therefore, the bull horns on this mask disappear altogether, and the "rays", merged with the "whiskers" into a single halo, meant the fifteenth day and the middle of the lunar month (Fig. 4, 1 б).

It was the "whiskers" on the three Itkol masks that personified lunarism, as the overall quality of all images of the censer. Therefore, the inclusion of "whiskers" into the numerical symbolization of the lunar month is associated only with its climax phase - the full moon. Iconographically, this idea is fairly conveyed by the merger of eight "whiskers" and seven "rays" into a jointed roundish halo similar to the image of the full moon (Fig. 4, 1 б).

Consequently, a single lunar image is imprinted on the Itkol censer, but in three different cadences representing the moon in the phases of the new moon, the first quarter and the full moon. Although the images are similar to the full moon mask, as well as to the character from Turist-2, are now considered to be "sun-headed". But the above arguments, in a certain sense, justify the diametrically opposite interpretation of such images.

The allegorical growth of the visible part of the crescent from the new moon to the full moon, which was figuratively represented by the "triptych" of the Itkol censer, is also indicative. When the censer turns from right to left, on the right side, the symbolization of the first quarter appears first, and then the image of the full moon phase. That is how (from right to left) in the Northern Hemisphere, the visible part of the growing moon visually grows, and the images on the Itkol censer exactly reproduce this dependency.

Only these phases are recorded in various names of the Sumerian moon god Sin: "Nanna" - "Full moon", "Su-en" - "Crescent" and "Ash-im-babbar" - "New World", i.e. young crescent moon. In accordance with the lunar 
phases, "all-temple" / "general" festivities were held on the first, seventh and fifteenth day of the month during the period of the third dynasty of Ur $\left(22^{\text {nd }}-21^{\text {st }}\right.$ centuries BC), and on the "day of reclining", i.e. on the day of the invisible ("dead") moon, special offerings were made. On this day of the new moon, the moon god went down into the underworld to hold court and make other decisions (Iakobsen, 1995: 143-144).

The tradition of Indo-Aryan sacrificial offerings also pays great attention to the day of the absence of the visible moon: "On the same day when it (the moon) should not be seen either in the east or in the west, a contributor should hurry up, because it is then when it (the moon) comes to this world, and it is on that (day) when the contributor waits for it here (on the sacrificial earth)" (Shatapatha-Brahmana, 11. 1. 1. 4). On this day, the creator of all the existing Prajapati also became the addressee of sacrificial offerings: "Verily, Prajapati, the Sacrifice, is the Year: the new moon is its gate, and the moon itself is the deadbolt of these gates" (Shatapatha-Brahmana, 11. 1. 1. 1). This is the time of the first sacrifice coinciding with the period of the moon that invisible before the new moon, when the contributor "will be able to enter the stronghold through the gate when the gate is open, and so he will reach heaven if he makes bonfires at the new moon" (see: Shatapatha-Brahmana, 11. 1.2.2).

Fourteen days later, the time came for the sacrifice on a particularly revered night of the full moon:

The full moon night was the first worthy of sacrifice Of days and nights during (ceremonies,) which is longer than night.

Who pleases you with sacrifices, oh, the one worthy of sacrifices,

Those creators of good deeds departed to your firmament.

(Atkharvaveda (Shaunaka), 7. 85. 3, 4).

Thus, comparative semantic correspondences are seen between the Itkol "triptych" and the mythopoetic content of archaic strata of the Near-Asian and Vedic literary monuments. The localization and chronology of these sources confirm the southwestern origins and partial continuity of Okunev mythology from the Near-Asian philosophical influences. At the same time, the indirect influence of the Okunev cultural corpus on the formation of the proto-mythopoetic tradition of the early Indo-Aryans of the Seima-Turbino era, which was embodied in the quoted Vedic texts after more than a millennium, is not excluded.

The interpretation of the phase of the first lunar quarter is preserved in the mythology of the Siberian peoples. In a Ket myth, the harmful female deity Hosedem in the fight against the Sun tears the crescent in half. In the Selkup version of a similar myth, the crescent is also torn in half by the Sun, which decided to marry it, and the old woman of the Lower World, Ylenta-kota (Ivanov, 1994: 79). Probably, with the image of the half-moon, which corresponds to the phase of the first quarter, etiological myths linked such dramatic collisions that determined the dynamics of the appearance of the Orb of Night.

\section{The image of the universe and the New Year sacrifice}

Two fragments of Samus ceramics depict monofigured images with the supposed lunar semantic meaning (Fig. 5). The reconstruction of the full-angle perspectives of these images indicates the likely quantitative symbolization of the idea of the full moon. The number of graphically restored "rays" of each mask is fifteen (Fig. 6), which indicates precisely this lunar phase. But since these images are unique and do not have adequate parallels in synstadial cultures, it is difficult to estimate their nature and generation. At the same time, there are other Samus images, the characteristic details of which resemble those of the lunar characters of the Okunev culture and from Turist-2.

From among the Okunev antiquities, two more analogies should be added to five of the six parallels cited by the authors of the Itkol censer finding (Poliakov and Esin, 2017: 343, Fig. 4) (Fig. 4). But the list of such correspondences is not limited to the range of single-cultural Okunev images. A series of anthropomorphic images with "whiskers" stands out among the ideograms presented on Samus ceramics 

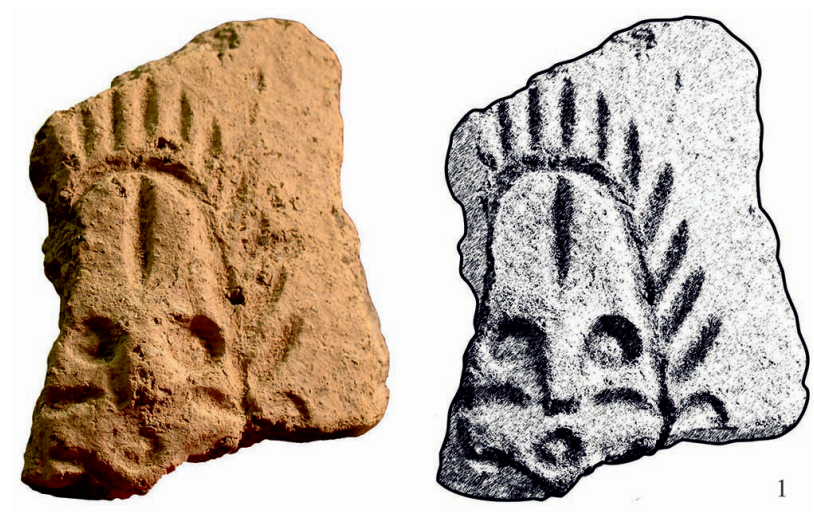

0

$3 \mathrm{~cm}$

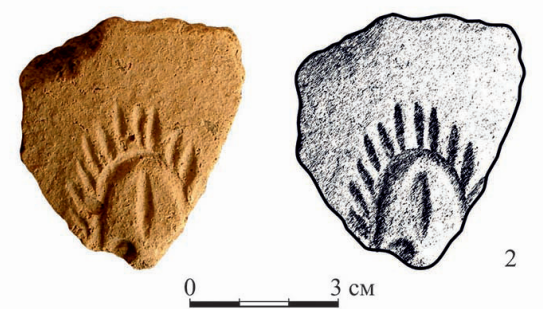

Fig. 5. Lunar masks. 1; 2 - Samus IV (photo by I.V. Kovtun)
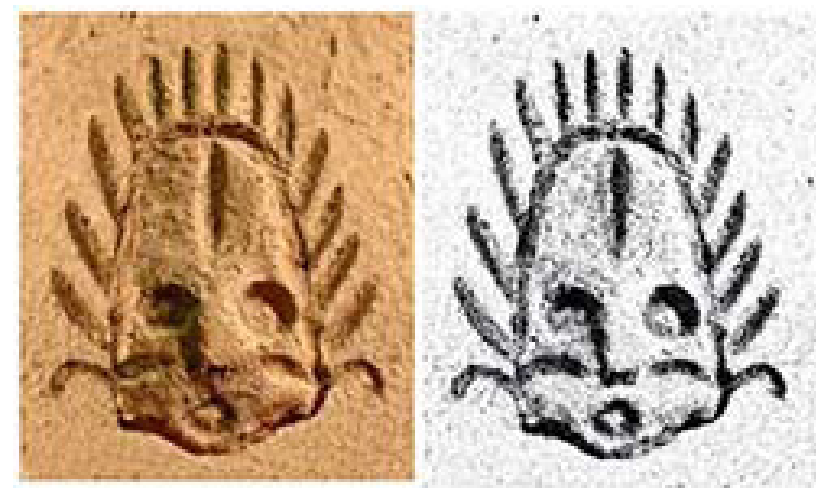

0
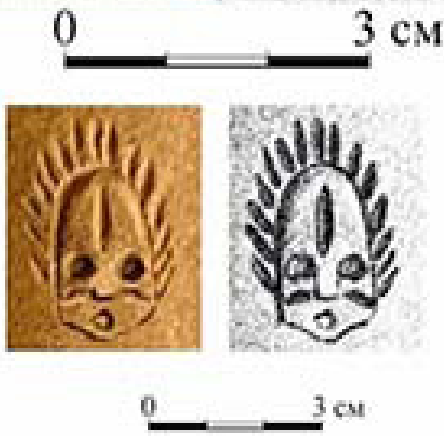

Fig. 6. Lunar masks. 1; 2 - Samus IV. Reconstruction 
(Fig. 7-9). Unlike Okunev, as well as a profile figure from the grave 1 of Turist-2, the Samus "whiskers" are ornamentally stylized and noticeably shorter. However, typologically, these are the same accessories attached to the side parts of the front contour of the images.
Like Okunev's masks with such details and a character from Turist-2, the Samus "whiskers" seem to be an accessory inherent in exclusively lunar images. This is confirmed by their combination with a stylized "crescent" cresting a "crown" of a number

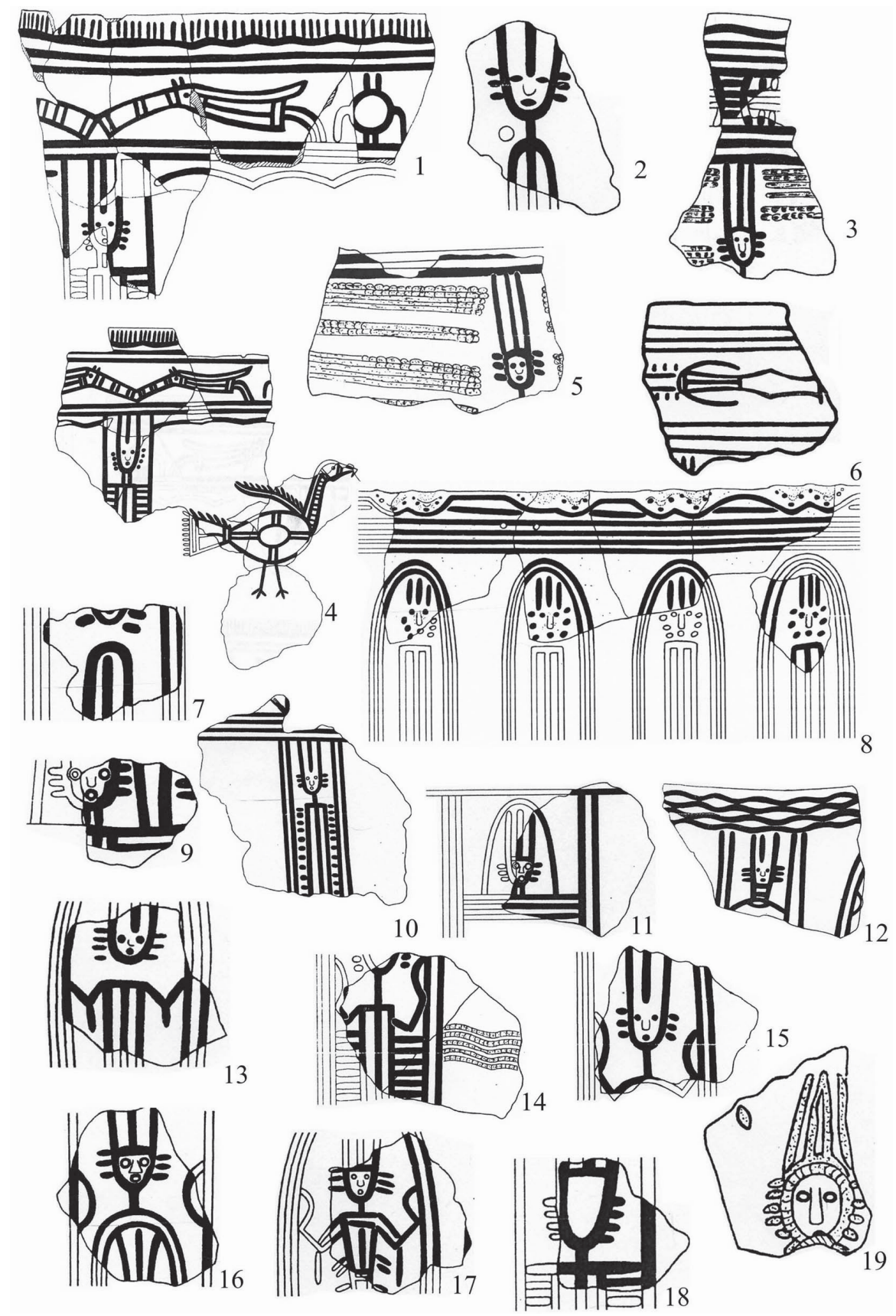

Fig. 7. Fragments with images of lunar characters. 1-19 - Samus IV. (drawings by lu.N. Esin) 

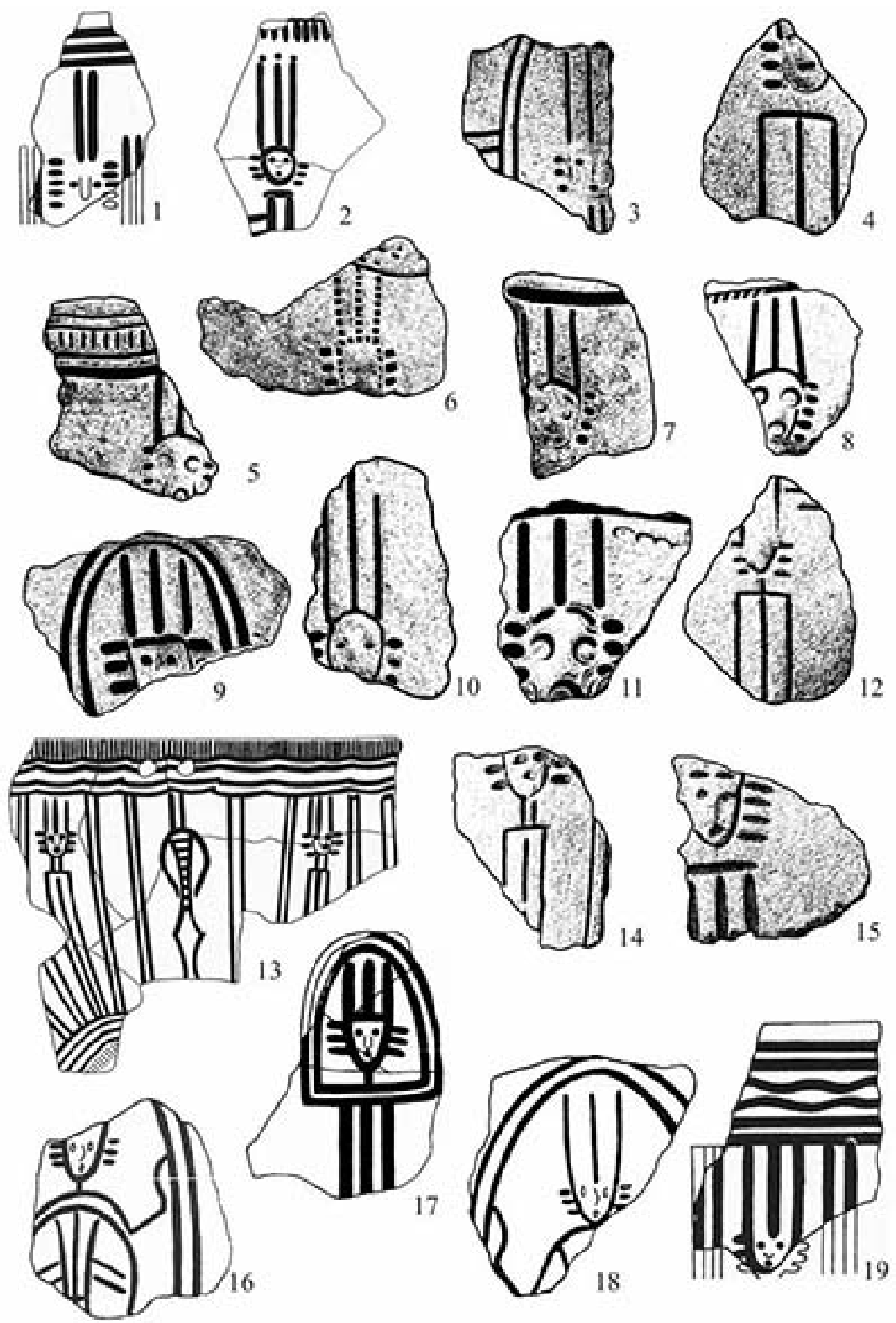

Fig. 8. Fragments with images of lunar characters.

1-19 - Samus IV. (1,2, 13, 16-19 - drawings by lu.N. Esin)

of Samus anthropomorphs with "whiskers" (Fig. 9, 6-14). In a more or less stylized form, such "crescents" are found at the highest point of the Okunev images belonging to different stages of culture (Fig. 9, 1-5). Moreover, the gradual stylization of the Okunev "crescents" to the level of the Samus ornamental graphics is obvious (Fig. 9, 5).

The mentioned Sumerian moon god Sin was also depicted like that, with the crescent moon above his head, and sometimes on the crescent moon (Turaev, 1990: 54; Tseren, 1976: 26). 

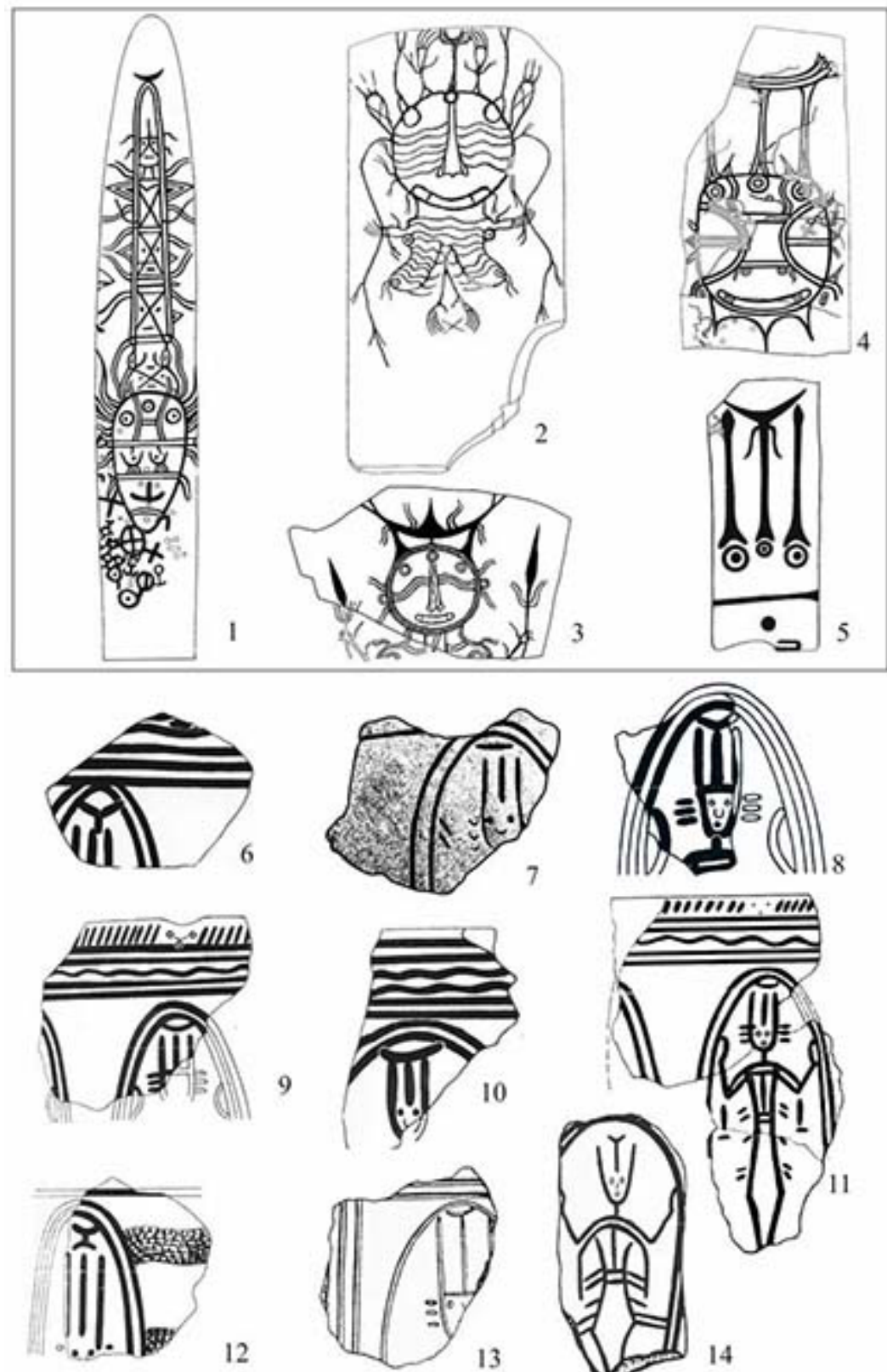

12
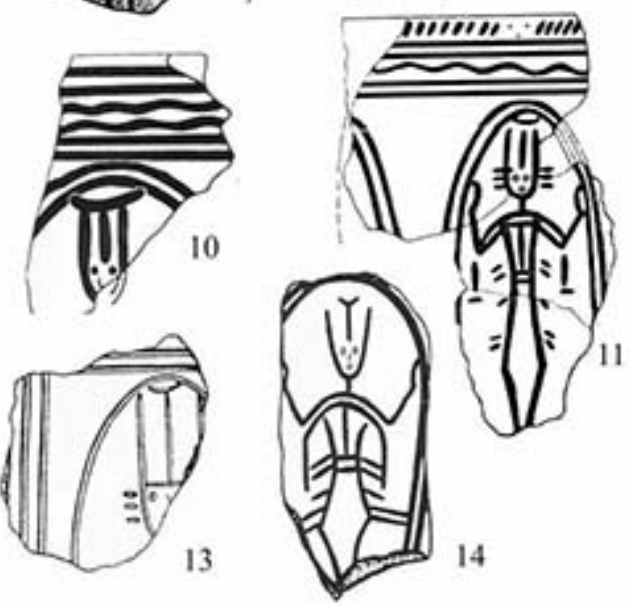

Fig. 9. Images and fragments with images of lunar characters with a "crescent". 1 - sculpture

"Kime tas" from lake Chernoe; 2 - Razliv X; 3, 5 - Chernovaya VIII; 4 - a stele, lake Chernoe; 6-14 - Samus IV (1-5 - according to N.V. Leont'ev and V.F. Kapel'ko; 6, 8-14 - drawings by lu.N. Esin)

The calendar-cosmogonic semantics of the Samus anthropomorphic-lunar characters with "whiskers" is confirmed by their inclusion in hierarchically structured compositions. A detailed reconstruction of the semantic meaning of this ideologically doctrinal Samus ideogram has been described previously (Kovtun, 2013: 285-295) (Fig. 9, 1, 4).

In the compositional centre, there is an anthropomorphic character with "whiskers" rep- 
resenting a prototype of the Vedic primordial deity, demiurge, "master of creation" supporting heaven and earth, "the only god over gods" Prajapati (Rigveda, 10: 121), or personifying the universe of the first man Purusha resembling the World Tree (Ogibenin, 1968: 62; Ivanov, 1974: 77-78). The "headgear" of this anthropomorphic image of the World Tree - a sacrificial pillar - is crowned by adjoining pairs of horse protomas. Each of the two closing horse faces is decorated with six transverse stripes (Fig. 9, 1, 4). The twelve stripes on the faces of the two horses signify the idea of sacrificing a horse likened to a year: "A year is the body of a sacrificial horse... Indeed, ashvamedha is something that radiates heat; its body is the year" (Upanishady: I. 1. 1; I. 2. 7). Six stripes on the adjoining faces of a horse pair symbolized the time of "contact" of two six-month cycles - "winter-year" and "summer-year", i.e. new year's early-spring period the festive horse sacrifice was arranged for.

The two-season calendar tradition, which distinguished winter-year and summer-year, was also preserved by some Siberian peoples: Evenks, peoples of Lower Amur and Sakhalin (Lushnikova, 2004: 11; Lushnikova, 2005: 12), Nenets, Selkups, northern and Kondinsky Mansi (Golovnev, 1995: 297, 301, 329, 349; Lushnikova, 2004: 11). Structural correspondence to similar calendar systems performed by the formula: $6+6=12$, is reflected in the Rigveda and Atharva Veda, where twelve months of the year are likened to "six twins" (Rigveda: I. 164. 15; Atkharva Veda (Shaunaka): X. 8. 5).

On the upper frieze of the Samus vessel, horse pairs alternate with a schematic mask separating and connecting them with braids (table). The mask on the vessels is biaxial, but on Samus ceramics, most of these images have four braids. In the Rigveda, there is a character who goes back to the plot signified by compositions with similar Samus characters:

A young wife with four braids, wonderfully decorated, With a face grated with fat, clothe in a proper manner. Two courageous eagles perched on her

(There) where the gods received the endowment of shares.

(Rigveda: X. 114. 3).
F.B.J. Kuiper believes that there should be an altar symbolizing the top of the mountain - the original hill from which four rivers flow - the girl's braids. The image of the World - Vedic cosmic tree is also indicated by a pair of birds (Kuiper, 1986: 157-158, 185-186) correlated with the moon and the sun (Ogibenin, 1968: 86). But according to archaeological data of the Middle East and the Aegean basin, V.V. Ivanov connects them with the "equivalence of bird symbols as the finial of columns... and the Heavenly Twins (Dioscuri) depicted on both sides of the Mother Goddess" (Ivanov, 1974: 76). The Heavenly Twins are accompanied by a mother or sister. The Ashvins, however, have always been portrayed with the goddess of dawn, Ushas, or with the daughter of the sun, Surya (Eliade, 1999: 102). Such a combination of a character as a young woman with the Heavenly Twins and the Ashvins (Ivanov, 1974: 131, 136) corresponds to the Samus composition resembling the mentioned architectural design. The anthropomorphic column is crowned by two horse protomas connected in a continuous row by masks with braids. It resembles a capital, i.e. an element between the top of the column and the ceiling. In the Middle East architecture, the role of capitals was often played by animal protomas (Vlasov, 2001: 502), and the Samus composition is structurally similar to such a construction (Fig. 9, 1, 4).

Symbolically important braids of the young girl find parallels in the autochthonous ethnographic material. Golden braids of the Mansi Kaltash-Ekva, who appears to be a beautiful young woman and is associated with the sacred top and morning light, descend from the sky to the ground, and daylight diverges from them, moonlight appears in them, etc. (Polosmak, Shumakova, 1991: 36; Sagalaev, 1991: 97; Sagalaev, 2001: 70). The listed symbolizations are correlated with the Vedic solar female deities on the Ashvin chariot and with the Samus picture of the upper frieze (Fig. 9, 1, 4).

The upper frieze of the composition is "supported" by a horizontal row of pillar-shaped anthropomorphs with "whiskers". They alternate with ornithomorphic images resembling geese or bustards that were interpreted as geese in the Vedic times: "Like geese, 
lined up in rows, pillars dressed in light have come to us" (Rigveda: I, 163. 10). This invariant mythopoetic formula, assimilating a number of geese / bustards to a series of sacrificial pillars, is represented by their alternation on a Samus vessel (Fig. 9, 1, 4).

The body of Samus birds has the shape of an egg and the image of another egg in the bird itself. The Samus assimilation of anthropomorphic pillars to birds with an egg corresponds to the worldview universal when "in myths on the world egg or in connection with them, one way or another, an image of the world tree or its closest alloelement - a pillar" emerges (Toporov, 2010: 225). But the World Egg is involved not only in the World Tree, but also in the divine horse twin pairs of the Ashvins and the Dioscuri: “... both of them connect with the world egg, which (like the world tree) contains simultaneously polar opposite series of binary symbolic relations. The tree (and the egg) as the centre of all world opposites naturally connects with the twins" (Ivanov, 1974: 136-137). According to one version, Dioscuri were born from an egg laid by Leda, after she was visited by Zeus in the guise of a swan. The Ashvins are the sons of Martanda - "from a dead egg (originating)" (Toporov, 2010a: 390-391). Therefore, paired horse protomas have semantic involvement in the egg inside geese / bustards on the body of the Samus vessel.

Like the sacrificial horse of ashvamedha, the image of a goose in a number of Siberian peoples was endowed with the features of a calendar marker of the turning points of the year. Such semantic meanings of the "goose" among the Samus and Siberian peoples come down to the motive of the new year's bird, which was involved in the idea of the Creation of the universe played out in new year's festivities (Kovtun, 2013: 293-294).

This parallel is confirmed by the symbolism of the twelve-month year, imprinted in the Samus composition on the faces of the horse protomas. According to Shatapatha-Brahmana, it is precisely the year that dwells in the pristine waters of the World Egg: "This golden egg floated as long as the year lasted" (Toporov, 2010a: 398), or: "Although there was no year then, this golden egg floated through the air for a year" (Shatapatha-Brahmana, XI. 1. 6. 1). Shatapatha-Brahmana connects the motive of the year with the golden egg and the creator of the existing Prajapati, and Brihadaranyaka Upanishad with the sacrificial horse of ashvamedha. All these images are presented on the Samus vessel (Fig. 9, 1, 4).

Equivalent to the very act of Creation, Prajapati assimilates to a year, and he appears from a golden egg a year later: "A year later, a person, this Prajapati, appeared from there (from a golden egg - I.K.); and then a woman, a cow or a mare, is born within a year; since Prajapati was born a year later. He broke this golden egg. Then, of course, there was no refuge: only this golden egg that carried him floated through the air for a year" (Shatapatha-Brahmana, XI. 1. 6. 2).

Continuing this line of semantic correspondences of the World Egg, V.N. Toporov notes that "The World Tree is also equal to a year, i.e. a complete circle around its axis or horizontal passage through the east, south, west and north and, accordingly, through four seasons" (Toporov, 2010: 226). This corresponds to a four-part breakdown of the egg body of the Samus bird (Fig. 9, 4). Consequently, both horse and bird characters of the Samus composition, including the image of the egg inside the bird, mean the idea of the birth of the universe personified by Purusha-Prajapati, embodied in the ritual practices of celebrating the new year.

Thus, in a pillar-shaped anthropomorph with "whiskers" one can guess a character that is meaningfully consonant with the image / images of Purusha-Prajapati: "At the end of the (first) year, Prajapati rose to his feet to stand on these worlds, made in such a way as a child tries to stand up by the end of the first year of life, so at the end of the year Prajapati stood up" (Shatapatha-Brahmana, XI. 1. 6. 5). A sacrificial horse participating in Ashvamedha, symbolizing a year, was considered as the personification of Prajapati offering himself as a sacrifice (Eliade, 2009: 272): "He (Prajapati I.K.) wished: 'May this [body] be suitable for me for sacrifice and may I incarnate with its help.' Then [it] became a horse; it became suitable for sacrifice, therefore the horse's sacrifice is called Ashvamedha" (Upanishady: I. 2. 7). 
Like the sacrificial horse personifying Prajapati, he was likened to a calendar year: "Prajapati reflected: 'Verily, I created my double, namely, a year'; therefore, they say: 'Prajapati is a year;' since he created it as his double" (Shatapatha-Brahmana, XI. 1. 6. 13), or: "Prajapati is indeed a year, and his joints are such: two intervals between day and night, days of the new and full moon and the beginning of the seasons" (Shatapatha-Brahmana: I. 6. 3. 35). It is in such a pair-symmetrical configuration that two vertical rows of "joints" of this Samus character are represented (Fig. 9, 1, 4).

So, in the semantic centre of the Samus calendar-cosmogonic composition, the original deity is presented, which is typologically reminiscent of the Vedic Purusha-Prajapati. The image of this Samus god is statuary and symbolizes the World Tree, i.e. the centre of the universe. This deity that gave rise to everything, including calendar time, was born from an egg in a bird close to a goose or a bustard. The original god embodies the calendar year and the laws of the calendar circle. Therefore, the upper frieze of the composition is crowned with horses adjacent to the pillar-shaped deity as a sacrificial pillar, and personifying the new year sacrifice on the universe's "birthday." At the same time, these paired-symmetrical horse protomas symbolized twin deities that were functionally close to the Ashvins / Dioscuri. The arrangement of the horses in the upper frieze of the vessel is similar to the place of Ashvins at the altar when partaking a sacrificial gift (Rigveda: IV, 45. 7). This is confirmed by their compositional connection with the climax image of a young girl with braids $-\mathrm{a}$ female solar deity akin to horse incarnations of the Samus "Ashvins." She is equivalent to the daughter of the sun, Surya, or the goddess of the morning dawn, Ushas following on the chariot of the Ashvin horse twins or with her (Rigveda: I. 118. 5; VIII. 9. 18).

The entire pictorial narrative refers to the calendar date of birth of the world, which took place thanks to the cosmogonic sacrifice of Purusha-Prajapati himself in a horse image. During sacrificial offering, a horse reproduces the act of Creation, personifying Prajapati (Eliade, 1999: 100-101; Eliade, 2000: 191;
Eliade, 2009: 272; Malamud, 2005: 119) who performs ashvamedha and is sacrificed to himself (Sementsov, 1981: 58). The Ashvamedha Indo-Aryan horse sacrifice was carried out during the full moon of the Chaitra month (Makhabkharata: XIV: 71. 1-2, 3-6; 82. 16-32; 83. 24-32), which is in March - April (Neveleva, 2003: 200; Lushnikova, 2004: 142, vol. 1), i.e. in the new year time of the spring equinox.

That is why the face of the Samus proto "Purushi-Prajapati" is framed by "whiskers" symbolizing a lunar nature of this original deity. Another important sign of the lunar nature of the Samus character is a "crescent" crowning its "headwear". Therefore, in this case, we can see iconographic symbolizations of the two lunar phases, which could account for the ritual practices of the Samus people. The anthropomorph with the "whiskers" and the "crescent" most likely represents the beginning of the sacrifice at the new moon. The mythologically subsequent context of the composition, including the horses at the figurative sacrificial column, indicates the phase of the full moon such a slaughter was arranged for. A similar sequence is recorded in the cited Vedic sources.

Thus, the plot reflects the cosmogonic and mytho-calendar representations of the Samus population, allowing the confinement of the main sacrifices to the new year festivities at the new moon and the full moon of the spring equinox.

\section{Conclusion}

Chronological priority of Okunev lunar characters. It is confirmed by the iconographic features of the Okunev, Krokhalevka and Samus images. But the "post-Okunev" iconography of the Krokhalevka and Samus images developed in diametrically opposite directions. Presumably, the Krokhalevka "triptych" from Turist-2 combines three-dimensionality and depth of composition with the symbolization of calendar cycles and the key moment of a year. Such a synthesis of space as a form and time as a content embodies the semantic meaning and, at the same time, determines the artistic style. It is no accident that the stylistic derivatives of the "triptych" from Turist-2 are seen in Kulai casting, which is the archaic form of 
this work. Such an interpretation is organically connected with the involvement of the Krokhalevka population of the Lower Tom Region in the creation of one of the earliest stages of rock art in the western foothills of the northwestern Altai-Sayan region. It is in the Lower Tom Region carvings where another characteristic motif is presented, which later became one of the iconographic markers of Kulai art. The bodies of a series of rock paintings of moose on the Tom river are represented with ornamental symbolization of an aorta and esophagus. After more than a millennium, it was manifested in Kulai metal plastic, as well as in moose figures on vessels from the settlement of Kizhirovo.

Other forms of pictorial expression of mythological representations are embodied in the Samus art. Creators of the Samus ideograms preferred ornamental stylization and unification of images. But even in these abstractions there are pictorial narratives with a complex compositional structure and an accumulated volumetric content.

The nature of iconographic and substantial convergence between the lunar characters of the Okunev, Krokhalevka and Samus cultures is due to the common root component in the composition of these formations. Therefore, the identified similarities do not apply to mechanical borrowings. They are caused by the generation within the framework of a united group of cultures connected by probable interactions, but most importantly, by a common southwestern cultural and genetic substrate.

\section{References}

Afanas'eva, V.K. (1994). Nanna [Nanna]. In Mify narodov mira [Myths of the world], Moscow, Rossiyskaya entsiklopediya, 2, 198.

Alekseenko, E.A. (1976). Predstavleniia ketov o mire [Ideas of the Kets about the World]. In Priroda $i$ chelovek $v$ religioznyk predstavleniiakh narodov Sibiri i Severa (Vtoraia polovina XIX - nachalo XX v.) [Nature and man in religious representations of the peoples of Siberia and the North (Second half of the $19^{\text {th }}$ - early $20^{\text {th }}$ centuries)]. Leningrad, Nauka, 67-105.

Atkharvaveda (Shaunaka) (2005). I-VII. In Vostochnaia literatura [Eastern literature], Moscow, I, $573 \mathrm{p}$.

Atkharvaveda (Shaunaka) (2007). VIII-XII, In Vostochnaia literatura [Eastern literature], Moscow, $2,293 \mathrm{p}$

Basova, N.V., Postnov, A.V., Nesterkina, A.L., Akhmetov, V.V., Morozov, A.A. (2017). Rezul'taty okhranno-spasatelnykh raskopok na poselenii Turist-2 v gorode Novosibirske v 2017 godu [Results of security and rescue excavations at the Turist-2 settlement in the city of Novosibirsk in 2017]. In Problemy arkheologii, etnografi, antropologii Sibiri i sopredelnykh territorii [Problems of archaeology, ethnography, anthropology of Siberia and adjacent territories]. Novosibirsk, IAET SO RAN, XXIII, 509-512.

Basova, N.V. (2018). Keramika iz mogil'nika bronzovogo vremeni na poselenii Turist-2 v Novosibirske [Ceramics from the Bronze Age burial ground at the Turist-2 settlement in Novosibirsk]. In Problemy arkheologii, etnografi, antropologii Sibiri i sopredelnykh territorii [Problems of archaeology, ethnography, anthropology of Siberia and adjacent territories]. Novosibirsk, IAET SO RAN, XXIV, 209-213.

Berezkin, Iu.E., Duvakin, E.N. (2018). Tematicheskaia klassifikatsiia i raspredelenie fol'klorno-mifologicheskikh motivov po arealam. Analiticheskii katalog [Thematic classification and distribution of folklore and mythological motifs by areas. Analytical catalog]. Available at: http://www.ruthenia.ru/folklore/ berezkin

Eliade, M. (1999). Izbrannye sochineniia. Ocherki sravnitel'nogo religiovedeniia [Selected Works. Essays on Comparative Religion]. Moscow, Ladomir, 488 p.

Eliade, M. (2000). Shamanizm: arkhaicheskie tekhniki ekstaza [Shamanism: archaic techniques of ecstasy]. Kiev, "Sofiia", 480 p.

Eliade, M. (2009). Istoriia very i religioznykh idei: Ot kamennogo veka do elevsinskikh misterii [A History of Faith and Religious Ideas: From the Stone Age to the Eleusinian Mysteries]. Moscow, Akademicheskii Proekt, 622 p. 
Gemuev, I.N. (1990). Mirovozzrenie mansi: Dom i Kosmos [Mansi Worldview: Home and Space]. Novosibirsk, Nauka, $232 \mathrm{p}$.

Golovnev, A.V. (1995). Govoriashchie kultury: traditsii samodiitsev i ugrov [Speaking cultures: traditions of Samoyeds and Ugrians]. Ekaterinburg, UrO RAN, 606 p.

Grintser, P.A. (1994). Rakhu [Rahu]. In Mify narodov mira [Myths of the world]. Moscow, Rossiiskaia entsiklopediia, 2, 372.

Grysyk, N.E. (1992). Shchuka v verovaniiakh, obriadakh i fol'klore russkikh [A pike in the beliefs, rites and folklore of Russian]. In Iz kul'turnogo naslediia narodov Vostochnoi Evropy. Sbornik Muzeia antropologii i etnografii [From the cultural heritage of the peoples of Eastern Europe. Collection of the Museum of Anthropology and Ethnography]. Saint-Petersburg, Nauka, XLV, 56-61.

Iakobsen, T. (1995). Sokrovishcha t'my. Istoriia mesopotamskoi religii [Treasures of Darkness. History of Mesopotamian Religion]. Moscow, Vostochnaia literatura, 293 p.

Istochniki po etnografii Zapadnoi Sibiri [Sources of Ethnography of Western Siberia] (1987). Tomsk, TGU, $284 \mathrm{p}$.

Ivanov, V.V. (1974). Opyt istolkovaniia ritualnykh i mifologicheskikh terminov, obrazovannykh ot asva - kon' (zhertvoprinoshenie konia i derevo asvattha $v$ drevnei Indii) [The experience of the interpretation of ritual and mythological terms derived from aśva - horse (sacrifice of a horse and aśvattha tree in ancient India)]. In Problemy istorii iazykov i kultury narodov Indii [Problems of the history of languages and culture of the peoples of India]. Moscow, Nauka, 75-138.

Ivanov, V.V. (1994). Lunarnye mify [Lunar myths]. In Mify narodov mira [Myths of the world]. Moscow, Rossiiskaya entsiklopediia, 2, 78-80.

Khariuchi, G.P. (2008). Zashchishchaiushchie prirodu tabu [Nature-Protecting Taboos]. In Materialy 2-i mezhdunarodnoi konferentsii po samodistike - posviashchaetsia 100-letiiu so dnia rozhdeniia Natal'i Mitrofanovny Tereshchenko (16-18 oktiabria 2008 g.) [Materials of the $2^{\text {nd }}$ international conference on self-mastery - dedicated to the $100^{\text {th }}$ birthday of Natalya M. Tereshchenko (October 16-18, 2008)]. Saint-Petersburg, Nestor-Istoriia, 278-291.

Klimishin, I.A. (1985). Kalendar' i khronologiia [Calendar and timeline]. Moscow, Nauka, 320 p.

Kovtun, I.V. (2013). Predystoriia indoariiskoi mifologii [The background of Indo-Aryan mythology]. Kemerovo, Aziia-Print, 702 p.

Kovtun, I.V. (2014). Shepot dukhov (Etnolingvokul'turnye ocherki mifologii nizhnetomskikh pisanits) [Whisper of Spirits (Ethnolinguocultural Essays on the Mythology of the Lower Tom Region Writings)]. Kemerovo, Aziia-Print, $171 \mathrm{p}$.

Kovtun, I.V. (2017). Obrazy i simvoly konskogo zhertvoprinosheniia na kinzhalakh seiminsko-turbinskoi epokhi [Images and symbols of horse sacrifice on the daggers of the Seima-Turbino era]. In Trudy V (XXI) Vserossiiskogo arkheologicheskogo s"ezda v Barnaule-Belokurikhe [Proceedings of the V (XXI) All-Russian Archaeological Congress in Barnaul - Belokurikha]. Barnaul, AGU, III, 110-116.

Kruchinina, A.V. (2004). Semanticheskoe prostranstvo obsko-ugorskoi i samodiiskoi etnonimii. Avtoreferat dissertatsii kandidata filologicheskikh nauk [The semantic space of the Ob-Ugric and Samoyed ethnonymy. Abstract of the PhD thesis]. Tyumen, $26 \mathrm{p}$.

Kuiper, F.B.J. (1986). Nebesnaia bad'ia [Tub of Heaven]. In Trudy po vediiskoi mifologii [Works on Vedic mythology]. Moscow, Nauka, 156-162, 183-188.

Lushnikova, A.V. (2004). Model' universuma drevnikh kalendarei (lingvisticheskaia rekonstruktsiia) [The model of the universe of ancient calendars (linguistic reconstruction)]. Moscow, Sovetskii pisatel', $258 \mathrm{p}$.

Lushnikova, A.V. (2005). Kalendari Severnoi Evrazii i Sibiri kak istochnik dlia rekonstruktsii drevnei kartiny mira [Calendars of Northern Eurasia and Siberia as a source for the reconstruction of an ancient picture of the world]. In Voprosy iazykoznaniia [Linguistics Issues], 5, 11-29.

Makhabkharata (2003). In Kniga chetyrnadtsataia. Ashvamedkhikaparva ili kniga o zhertvoprinoshenii konia [The Fourteenth Book. Ashvamedhikaparva, or a book about the sacrifice of a horse]. Saint-Petersburg, Nauka, $308 \mathrm{p}$. 
Malamud, Sh. (2005). Derevnia i les v ideologii brakhmanistskoi Indii [Village and forest in the ideology of Brahminist India]. In Malamud Sh. Ispech mir: ritual i mysl'v drevnei Indii [Ispech world: ritual and thought in ancient India]. Moscow, Vostochnaia literatura, 119-140.

Neveleva, S.L. (2003). Epicheskaia ashvamedkha [Epic Ashvamedha]. In Makhabkharata. Kniga chetyrnadtsataia. Ashvamedkhikaparva ili kniga o zhertvoprinoshenii konia [Mahabharata. The Fourteenth Book. Ashvamedhikaparva, or a book about the sacrifice of a horse]. Saint-Petersburg, Nauka, 196213.

Ogibenin, B.L. (1968). Struktura mifologicheskikh tekstov "Rigvedy" (Vediiskaia kosmogoniia) [The structure of the mythological texts of the Rigveda (Vedic cosmogony)]. Moscow, Nauka, $115 \mathrm{p}$.

Poliakov, A.V., Esin, Iu.N. (2017). Kuril'nitsa s antropomorfnymi izobrazheniiami iz ranneokunevskogo pogrebeniia mogil'nika Itkol-II [A censer with anthropomorphic images from the early Okunev burial of the Itkol-II burial ground]. In Trudy V (XXI) Vserossiiskogo arkheologicheskogo s"ezda v BarnauleBelokurikhe [Proceedings of the V (XXI) All-Russian Archaeological Congress in Barnaul-Belokurikha]. Barnaul, AGU, I, 340-345.

Polosmak, N.V., Shumakova, E.V. (1991). Ocherki semantiki kulaiskogo iskusstva [Essays on the semantics of Kulai art]. Novosibirsk, Nauka, $92 \mathrm{p}$.

Rigveda. Mandaly I-IV [Mandalas I-IV] (1989). Moscow, Nauka, $767 \mathrm{p}$.

Rigveda. Mandaly IX-X [Mandalas IX-X] (1999). Moscow, Nauka, 559 p.

Sagalaev, A.M. (1991). Uralo-altaiskaia mifologiia: Simvol i arkhetip [Ural-Altai Mythology: Symbol and Archetype]. Novosibirsk, Nauka, 155 p.

Sagalaev, A.M. (2001). Kaltas-ekva [Kaltas-Equa]. In Mifologiia mansi [Mansi Mythology]. Novosibirsk, IAEt SO RAN, 70-71.

Seleshnikov, S.I. (1970). Istoriia kalendaria i khronologiia [History of calendar and chronology]. Moscow, Nauka, $224 \mathrm{p}$.

Sementsov, V.S. (1981). Problemy interpretatsii brakhmanicheskoi prozy. Ritualnyi simvolizm [Problems of interpretation of brahminical prose. Ritual symbolism]. Moscow, Nauka, Glavnaia redaktsiia vostochnoi literatury, $181 \mathrm{p}$. $383 \mathrm{p}$.

Shatapatkha-brakhmana [Shatapatha-brahmana] (2009). Moscow, Vostochnaya literatura, I; X,

Spodina, V.I. (2001). Predstavleniia o prostranstve v traditsionnom mirovozzrenii lesnykh nentsev Nizhnevartovskogo raiona [Representations of space in the traditional worldview of the Forest Nenets of the Nizhnevartovsk region]. Novosibirsk, Izdatelskii Tsentr "Agro", Izdatelskaia gruppa "Soliaris", «TSERIS», $124 \mathrm{p}$.

Temkin, E.N., Erman, V.G. (2000). Mify Drevnei Indii [Myths of Ancient India]. Moscow, OOO «Izdatelstvo Astrel», OOO «Izdatelstvo AST», $560 \mathrm{p}$.

The Satapatha-Brâhmana. According to the text of the Mâdhyandina school. Part V. Books XI, XII, XIII, and XIV. The sacred books of the east. Vol. XLIV. (1900). Oxford, At the clarendon press, $596 \mathrm{p}$.

Toporov, V.N. (2010). "Mirovoe derevo". Opyt semioticheskoi interpretatsii ["World tree". The experience of semiotic interpretation]. In Toporov V.N. Mirovoe derevo: Universalnye znakovye kompleksy [Toporov V.N. World tree: universal iconic complexes]. Moscow, Rukopisnye pamiatniki Drevnei Rusi, 1, 210-262.

Toporov, V.N. (2010a). K rekonstruktsii mifa o mirovom iaitse (po materialam russkikh skazok) [To the reconstruction of the world egg myth (based on Russian fairy tales)]. In Toporov V.N. Mirovoe derevo: Universalnye znakovye kompleksy [Toporov V.N. World tree: universal iconic complexes]. Moscow, Rukopisnye pamiatniki Drevnei Rusi, 1, 390-407.

Tseren, E. (1976). Lunnyi bog [Moon god]. Moscow, Nauka, 382 p.

Turaev, B.A. (1900) Sin [Sin]. In Entsiklopedicheskii slovar' Brokgauza i Efrona [Brockhaus and Efron Encyclopaedic Dictionary]. Saint-Petersburg, XXX, 493.

Upanishady v 3-kh knigakh. Brikhadaraniaka Upanishada [Upanishads in 3 books. Brihadaranyaka Upanishad] (1992). Moscow, Nauka, 1, 239 p. 
Vlasov, V.G. (2001). Bolshoi entsiklopedicheskii slovar' izobrazitel'nogo iskusstva [Great Encyclopaedic Dictionary of Fine Arts]. Saint-Petersburg, LITA, 3, 848 p.

Zaika, A.L., Basova, N.V., Postnov, A.V. (2018). Antropomorfnaia mnogofigurnaia kompozitsiia iz pogrebeniia na poselenii Turist-2 v Novosibirske [Anthropomorphic multi-figured composition from a burial in the settlement of Turist-2 in Novosibirsk]. In Izobrazitel'nye i tekhnologicheskie traditsii rannikh form iskusstva [Fine and technological traditions of early art forms]. Moscow, Kemerovo, Trudy SAIPI, XII, 2.

\title{
Лунарные образы в культурных традициях юга Западной Сибири во второй половине III - начале II тыс. до н.э.
}

\author{
И.В. Ковтун* \\ Федеральный исследовательский иенттр угля и углехимии СО РАН \\ Российская Федерация, Кемерово
}

\begin{abstract}
Аннотация. В статье выделена серия разнокультурных изображений эпохи развитой бронзы юга Западной Сибири, связанных общим смысловым значением. Обосновывается лунарная семантика окуневских, крохалевских и самусьских антропоморфных персонажей, передающих идею значимых лунных циклов, главным образом новолуния, первой четверти и полнолуния. Реконструируются мировоззренческие представления населения данных культур, исследуются вероятные истоки лунарного культа и особенности подобных воззрений у каждого сообщества. Выявлены специфические иконографические способы передачи схожих идейных стереотипов различными изобразительными средствами, присущими культурным группам Верхнего Приобья, Нижнего Притомья и Среднего Енисея во второй половине III — начале II тыс. до н.э.
\end{abstract}

Ключевые слова: лунарные образы, юг Западной Сибири, окуневская культура, крохалевская культура, самусьская культура, мировоззрение, изобразительное искусство, орнаментальная графика.

Научная специальность: 07.00.00 - исторические науки и археология. 